\title{
11
}

\section{Fichte's Deduction of the Moral Law}

\author{
Owen Ware
}

Instead of enumerating in detail the advantages of such a deduction, it is enough to note that by means of it a science of morality first comes into being, and science, where it is possible, is an end in itself.

—Fichte, The System of Ethics (GA I/5:33, my translation)

It is often assumed that Fichte's aim in Part I of the System of Ethics (1798) is to provide a deduction of the moral law, the very thing which Kant-after years of unsuccessful attempts-deemed impossible. On this familiar reading, what Kant eventually viewed as an underivable "fact" (Factum), the authority of the moral law, is what Fichte traces to its highest ground in what he calls the principle of the I as such. ${ }^{1}$ However, scholars have largely overlooked a passage in the System of Ethics where Fichte explicitly invokes Kant's doctrine of the fact of reason with approval, claiming that consciousness of the moral law grounds our belief in freedom (GA I/5:65). On the reading I defend in this chapter, Fichte's invocation of the Factum is consistent with Fichte's grounding the moral law's authority in the principle of the I when we distinguish (a) the feeling of moral compulsion from (b) the moral law itself. As we shall see, a failure to draw this distinction led one of Fichte's nineteenth century critics, Christfried Albert Thilo, to conclude that his deduction of the moral law is viciously circular. ${ }^{2}$ Although this objection misses its mark, it is

\footnotetext{
O. Ware $(\bowtie)$

Department of Philosophy, University of Toronto, Toronto, ON, Canada e-mail: owen.ware@utoronto.ca
} 
instructive for showing the extent to which Fichte remains committed to the fact of reason in grounding a science of morality.

Before we begin, a few caveats are in order. First, because I am limiting the scope of my discussion to the System of Ethics, I will not take it as a condition of success for my interpretation that it coheres with everything Fichte says during the so-called Jena period (1793-1800). One finds his views changing over these years, if only in presentation, and there is no reason to expect perfect continuity between them. Second, it is not my intention here to present a full comparison of Fichte's project of moral justification to Kant's, although the question of their affinity at times becomes unavoidable. Departing from the familiar reading, I will argue that Fichte embraces some version of Kant's claim that consciousness of the moral law "discloses" our freedom to us (CPrR 5:29-30), or what I will call the disclosure thesis. On my account, the real difference between their respective projects lies in Fichte's claim that freedom and morality are not two thoughts but "one and the same thought" (GA $\mathrm{I} / 5: 64$ ), or what I will call the identity thesis. Lastly, it is worth stating from the outset that my main concerns are interpretive, and I will not try to defend the plausibility of Fichte's approach. But in a final section I will return to the objection that Fichte's deduction is viciously circular, and there I shall explain why this objection is without merit.

\section{Normativity and the Science of Ethics}

As a first step, it is important to understand why Fichte views his system of ethics, not as a self-standing theory, but as a theory "according to the principles of the Doctrine of Science" (nach den principien der Wissenschaftslehre). As he explains in the Introduction, both theoretical philosophy and practical philosophy share the task of explaining a relation of correspondence between what is "subjective" and what is "objective" (GA I/5:21). The difference between the two, Fichte adds, is that theoretical philosophy is the science of explaining how something objective corresponds to something subjective (how the world corresponds to the self), whereas practical philosophy is the science of explaining how something subjective corresponds to something objective (how the self corresponds to the world). Simply stated, the claim of the Wissenschaftslehre is that these relations of correspondence are intelligible only if we assume a point of absolute unity between the two, a point where the subjective and the objective are "not at all distinguished from one another but are completely one [ganz Eins]" (GA I/5:21). This is what Fichte calls the "absolute identity of the subject and the object in the I," or "I-hood" (Ichheit) 
for short (GA I/5:21). I-hood therefore serves as the first principle of his system as a whole, the single root from which particular theoretical and practical sciences can grow.

My reason for foregrounding this statement from the Introduction is that it sheds light on the relationship Fichte conceives between a deduction in general and the first principle of his system. In the first case, theoretical philosophy can have success only if it recognizes that what we designate with the category of the objective- the feeling of necessity that comes with our representation of the world-is nonetheless a representation. What we designate as objective is not a world given to us, but a consciousness of a world given to us - not a reality wholly independent of the I, but a consciousness of a reality wholly independent of the I. But that is just to say that without a link to the I, we lose all grounds to speak intelligibly about what is. Theoretical philosophy is properly transcendental only when it treats what is objective as a form of "necessary thinking" that traces back to the first principle of I-hood (GA I/5:22). Similarly, Fichte argues, practical philosophy can have success only if it recognizes that what we designate with the category of the objective-the feeling of necessity that comes with our representation of duty-is nonetheless a representation. So what we designate as objective is not a command given to us, but a consciousness of a command given to us- not an authority wholly independent of the I, but a consciousness of authority wholly independent of the I. ${ }^{3}$ But that is just to say that without a link to the I, we lose all grounds to speak intelligibly about what ought-to-be. Practical philosophy is properly transcendental only when it treats what is objective as a form of necessary thinking that traces back to the first principle of I-hood (GA I/5:28).

Although this gives us nothing more than a sketch, what I have said should help explain why Fichte introduces Part I of the System of Ethics with a piece of moral phenomenology:

It is claimed that a compulsion [Zunöthigung] expresses itself in the mind of a human being, a compulsion to act entirely apart from external ends, but absolutely and simply to perform the action, and a compulsion to refrain from acting, equally apart from external ends, but absolutely and simply to leave the action undone. Insofar as such a compulsion manifests itself in someone necessarily, as surely as he is a human being, one calls this constitution the moral or ethical nature of a human being as such. (GA I/5:33)

What Fichte wants to highlight from the outset of the book is a particular feeling: the feeling of having to perform some actions, simply for the sake of performing them, and the feeling of having to avoid other actions, simply for 
the sake of avoiding them. The issue at hand, then, is not yet the content of our moral obligations, but the way we experience them as binding, constraining, or limiting our activity. The fact (Thatsache) Fichte uses to set the stage for his deduction of the moral law is therefore the fact of normativity itself. It is an analogue of our representation of objectivity in the world, since we also experience the world as limiting us. And that is why the System of Ethics proceeds according to the principles of the Wissenschaftslehre. The aim of Part I is to trace our common consciousness of normativity to its higher (indeed highest) ground.

Of course, some of us may be content to treat this felt compulsion as a fact, without asking after its highest ground of possibility, and some of us may even decide to affirm it in an attitude of belief or faith (Glaube). This amounts to what Fichte calls factual or common cognition of our ethical nature, and he says quite explicitly that such cognition is all we need to cultivate "both a dutiful disposition and dutiful conduct" (GA I/5:34). The everyday phenomenology of moral compulsion indicates the presence of a practical imperative, and this imperative appears to be absolute (independent of extrinsic ends) and categorical (valid in all circumstances). Assenting to this appearance in an attitude of faith is sufficient for living a moral life, Fichte argues, because it grants this feeling priority over all other motives, desires, or inclinations that may call upon our attention. A deduction becomes pressing, then, only for someone who wants genetic or scientific cognition of our ethical nature. Such a person must "raise himself above the standpoint of ordinary consciousness" because he wants to know how this compulsion "originates" (GA I/5:34). Yet these two modes of cognition are not entirely separate. For Fichte, the kind of deduction appropriate to transcendental philosophy is one that vindicates the fact of normativity. Genetic cognition has the aim of uncovering the rational origin of this feeling in a way that defends, rather than deflates, our common moral consciousness.

But this raises an urgent question: How is such a defense possible? How are we to go about tracing the feeling of compulsion to its highest ground in the principle of I-hood? One obstacle standing in the way of such a deduction is that the principle of I-hood is, by Fichte's own admission, unthinkable. It designates the "absolute identity of the subject and the object in the I," but this identity, he is quick to point out, "can only be inferred" (GA I/5:21). In all cases consciousness requires a separation between what is subjective and what is objective: I am conscious of an object only insofar as I distinguish myself, as the one who is conscious, from the object of my consciousnesseven if that object is myself (GA I/5:21; cf. GA I/4:242). Consequently, we cannot become conscious of the point where the subject and the object are 
one and the same, and so we cannot demonstrate the first principle of the entire Doctrine of Science as an "immediate" fact of consciousness. For this reason I think it would be a mistake to assume that Fichte wants us to employ the principle of I-hood in a conventional, unilinear manner and proceed stepby-step to the feeling of compulsion. But then what role, if any, is this first principle suited to play? If we cannot comprehend the unity of the I as such, prior to its separation into what is subjective and what is objective, how can we hope to acquire genetic cognition of our ethical nature, as Fichte seeks to provide?

\section{Fichte's Deduction of the Moral Law}

The answer brings us directly to what is most innovative about Fichte's deduction: its three-part structure. The unthinkability of I-hood leads him to develop an unorthodox, multi-lateral strategy for deriving the feeling of compulsion. ${ }^{4}$ In this connection an important hint comes to light when Fichte describes the "path" his deduction will follow:

We will assign ourselves the task of thinking of ourselves under a certain specified condition and observing how we are required to think of ourselves under this condition. From the property of ourselves that we find in this way, we will then derive, as something necessary, the moral compulsion noted earlier. $(\mathrm{GA} \mathrm{I} / 5: 35)^{5}$

More specifically, the method Fichte employs in $\$ \$ 1-3$ of Part I involves issuing a task, seeking a solution, drawing a result, and then revealing a limit to that result, thereby motivating a new task $k^{6}$ :

1. Our task in $\$ 1$ is to isolate what is most essential to the self, and Fichte's solution is to approach the I under its objective aspect, as it is given in reflection (as willing). This leads him to the desired result: that what is most essential to the self is a tendency to self-activity. But the result is limited, since it does not show how we become conscious of this tendency (GA I/5:47).

2. Our task in $\$ 2$ is then to show how we become conscious of our tendency to self-activity, and Fichte's solution is to approach the I anew under its subjective aspect, as it is engaged in reflection (as intelligence). This leads him to the desired result: that we become conscious of our tendency to 
self-activity the moment we grasp our indeterminacy or lack of a pre-given nature (GA I/5:51). ${ }^{7}$

3. However, Fichte tells us that this result is also limited. While it shows how we become conscious of our capacity to generate action from ourselves, it does not yet reveal a positive determination of this capacity (GA I/5:52). For this reason Fichte formulates a new task in $\$ 3$, to show how we become conscious of our tendency to self-activity, not as a merely possible mode of willing, but as an actual mode of willing. The task of $\$ 3$ marks a decisive turning point in the System of Ethics, leading Fichte to argue, rather strikingly, that there is only one way our tendency to self-activity can manifest itself, namely, as a drive (Trieb), which he defines as "a real, inner explanatory ground of an actual self-activity" (GA I/5:55; cf. GA I/2:418). Fichte adds right away that, since the drive in question concerns our original selfactivity, we must regard it as essential to the I as such, and here he offers an important remark: that this drive relates to the "entire I" (GA I/5:54). By this I take him to mean that when we consider an I divided by selfreflection, we now see that the I reflected upon is posited as a drive, that is, as an actual striving to self-activity, and that the I engaged in reflection is an intellect, which then subsumes this drive under a concept. The drive relates to the entire I, in other words, because it concerns both the I given in reflection and the I engaged in reflection, appearing first as a real ground of activity (objectively), and then as the very concept through which we direct our self-determination (subjectively) (GA I/5:56-57). But granting all this, we must still ask: How does the concept of a drive put us closer to the goal of solving the third task? What does this drive offer to consciousness, if not the awareness of a mere capacity (Vermögen) to determine ourselves freely?

Anticipating this question, Fichte explains that the drive to self-activity offers itself to consciousness as a thought (Gedanke) or manner of thinking (Denken), for the simple reason that it engages our power of intelligence. ${ }^{8}$ So it seems that all we must do in order to solve the task of $\$ 3$ is to analyze this manner of thinking further, and that is what Fichte will soon recommend. But there is a problem at hand, as he is also ready to point out. The concept of a drive that relates to the entire I is precisely the concept of a drive that relates to the I as a subject-object unity, and Fichte reminds us once again that this unity is unthinkable (GA I/5:60). "The entire I is determined by the drive to absolute self-activity, and this determination is the thought we are considering. But the entire I cannot be grasped, and for this reason a determinacy of 
the entire I cannot be grasped immediately either" (GA I/5:60). This means that if we are to analyze the manner of thinking manifesting from our drive to self-activity, we must take a multi-lateral approach-employing what Fichte now calls the "law of reciprocal interaction" (Gesetze der Wechselwirkung) whereby we isolate the manner of thinking first in its subjective and objective aspects, and then put the two together synthetically. "One can approximate the determinacy of the entire I," he writes, "only by means of a reciprocal determination of what is subjective by what is objective, and vice versa, and this is the path we shall take" (GA I/5:60). ${ }^{\text {? }}$

\section{The Law for Freedom}

Unfortunately, instead of moving directly to this path, Fichte raises the specter of an antinomy which, if left unresolved, would threaten the System of Ethics at its very foundation. ${ }^{10}$ The antinomy emerges from a possible objection one could level against the idea that a determinate thought or manner of thinking necessarily arises for the intellect. The problem is that, by Fichte's stated definition, the intellect is supposed to be free, agile, and spontaneousthe very characteristics that render it void of a pre-given nature-such that "no thoughts can ever be produced in it" (GA I/5:58). To say that a determinate thought necessarily arises for the intellect therefore appears to commit us to a pair of contradictory claims: that our drive to self-activity produces a thought in the intellect (the thesis), and that the intellect is absolutely free from such production (the antithesis). But Fichte says that when the thesis is properly qualified, "we will see that both [assertions] can very well stand alongside each other" (GA I/5:58). In this respect he thinks that the way to dissolve the antinomy is to apply what he later calls the "rules of synthetic method," whereby we resolve the contradiction between the thesis and the antithesis through a higher synthesis, "in such a way that the two would be posited as one and the same" (GA I/5:104).

On my interpretation, Fichte arrives at this synthesis by invoking the law of reciprocal interaction mentioned above. It unfolds over the course of three steps:

1. In the first step, Fichte begins by inviting the reader to consider what is subjective in the manner of thinking arising from our drive to self-activity under the aspect of objectivity. The "essence" of objectivity, he explains, is what is fixed, unchangeable, and stable (GA I/5:60). So when we apply this 
category to the manner of thinking in question, we get a command for the intellect to give itself a fixed law.

2. In the second step, Fichte invites the reader to consider what is objective in the manner of thinking arising from our drive to self-activity under the aspect of subjectivity. The "essence" of subjectivity, he explains, is what is free, agile, and spontaneous (GA I/5:61). So when we apply this category to the law just derived, we get a command for the intellect to think of itself as free.

3. In the third and final step, Fichte reminds us that we can approximate the unity of the two preceding thoughts "in accordance with the law of reciprocal interaction," that is, "by thinking freedom as determining the law and the law as determining freedom" (GA I/5:64). When we then combine the objective aspect of the thought (that of the intellect giving itself a law) with the subjective aspect of the thought (that of the intellect thinking of itself as free), we get a command for the intellect to determine itself by its own law of freedom (GA I/5:64).As Fichte expresses this last point, speaking now to the reader: "When you think of yourself as free, you are required to think your freedom under a law; and when you think of this law, you are required to think of yourself as free" (GA I/5:64). And the key point Fichte has been preparing us for is the insight that freedom and morality "are not two thoughts, one of which would depend on the other" but are really two aspects of "one and the same thought" (Ein und ebenderselbe Gedanke) (GA I/5:65)—or what I am calling the identity thesis. Once we establish this thesis, any tension between freedom and morality dissolves, and we can put the specter of an antinomy to rest. There is nothing contradictory in the claim that our drive to self-activity produces a necessary manner of thinking-not when we see, having followed the course of Fichte's deduction, that this manner of thinking is a law that the intellect gives to itself.

\section{The Higher Synthesis}

But how does the identity thesis bring Fichte's deduction to a close? Recall what he says at the beginning of Part I: that

we shall assign ourselves the task of thinking of ourselves under a certain specified condition and observing how we are required to think of ourselves under this condition. From the property of ourselves that we find in this way, we will 
then derive, as something necessary, the moral compulsion noted earlier. (GA I/5:35)

The goal is to attain genetic cognition of our ethical nature, since we want to know where a shared feeling of "compulsion to act entirely apart from external ends" comes from. And Fichte's point is that a successful deduction must trace all such feelings back to the principle of I-hood. Yet the reason why he adopts a multi-lateral strategy, I have argued, is that the principle of I-hood is an unthinkable unity of what is subjective and what is objective. So the only way we can attain genetic cognition of our ethical nature is to apply a synthetic method and reveal, through the law of reciprocal interaction, that we are required to think of ourselves under the law of our own freedom. Only then can we turn back to the "fact" Fichte introduced at the beginning of Part I. The necessity of thinking our freedom under a law (itself a mere aspect of the unity of the I) reveals the origin of the feeling of compulsion in ordinary moral life.

This completes Fichte's deduction, which we may summarize ${ }^{11}$ as follows (Fig. 11.1):

$$
\overbrace{\text { Object }=\text { Subject }}^{\mathrm{I}(\mathrm{Ich})}
$$

Separation in Consciousness

$\underbrace{\text { Objective }} \underbrace{\text { Subjective }}$

\$1. 'I' given in reflection (will) §2. 'I' engaged in reflection (intelligence)

§3. Drive to Self-Activity (Qua Thought)

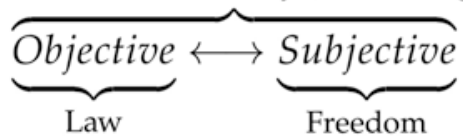

Reciprocal Interaction

$\overbrace{\text { Law for Freedom }}$

Ground of the Feeling of Compulsion

$\overbrace{\text { Moral Law }}$

Fig. 11.1 Fichte's deduction of the moral law 
One advantage of this interpretation, if correct, is that it explains how we become conscious of our tendency to self-activity, not as a merely possible mode of willing, but as an actual mode of willing. Remember that what was missing from $\$ 2$, and the reason why our analysis reached a limit, was that we only got as far as positing our capacity to act freely. This was important for illuminating the concept of freedom that we assign to the intellect: the freedom to produce action from itself. But this got us no further than the concept of an "empty, undetermined capacity of self-sufficiency" (GA I/5:63). "There lies in this concept," Fichte explains, "not the least datum indicating that or what kind of actuality is to be thought" (GA I/5:63). As we discover, the "datum" by which we cognize ourselves as positively free only appears in $\$ 3$, in the manner of thinking the intellect under its own law. For the law Fichte that introduces in this section arises from a real drive to self-activity, the expression of which is a command for the intellect to be free (i.e., to be absolutely self-sufficient).

A related advantage of this interpretation is that it explains why, after concluding his deduction, Fichte invokes Kant's claim that consciousness of the moral law "discloses" our freedom to us (CPrR 5:29-30), or what I am calling the disclosure thesis. After saying that freedom and morality are "one and the same," Fichte writes that in "many places Kant derives conviction in our freedom from consciousness of the moral law" (GA I/5:64), adding:

This is to be understood as follows. The appearance of freedom is an immediate fact of consciousness [unmittelbares Factum des Bewusstseyns], and by no means the consequence of another thought. However, as was recollected above, one could want to explain this appearance further and thereby change it into an illusion. That one does not explain this appearance further- there is no theoretical reason for this, but there is a practical one: the firm decision to grant primacy to practical reason, to hold the moral law [das Sittengesetz] as the true and final vocation of one's being, and not to go beyond the moral law through rationalization. (GA I/5:65)

As this passage makes clear, Fichte interprets Kant's disclosure thesis approvingly as a claim about the reason we have for assenting to the appearance of freedom. Our faith in this appearance can be derived, as he puts it, "from consciousness of the moral law" (GA I/5:65). In Kantian terms, this means that while freedom is the essence of the law, the law is the ground for cognizing freedom, for only the moral law reveals the positive determination of our tendency to self-activity. 


\section{Problems and Prospects}

The textual evidence just reviewed makes it clear that there is, by Fichte's lights, a close affinity between his deduction of the moral law and Kant's disclosure thesis. However, what Kant actually says in the Critique of Practical Reason (1788) throws this affinity into question. After showing why freedom and morality "reciprocally imply each other" (CPrR 5:29), Kant asks where our "cognition of the unconditionally practical starts," whether from freedom or from the law itself (CPrR 5:29). He then proceeds to eliminate both freedom (on the grounds that freedom is not an object of experience), and nature (on the grounds that nature only teaches us the rule of causal mechanism), concluding that it must be the moral law which first "leads" us to a positive concept of freedom (CPrR 5:29-30). Kant prepares the reader for this claim in the Preface, where he explains why freedom is the ratio essendi of the moral law and the moral law the ratio cognoscendi of freedom: "For had not the moral law already been distinctly thought in our reason, we should never consider ourselves justified in assuming such a thing as freedom (even though it is not self-contradictory). But were there no freedom, the moral law would not be encountered at all in ourselves" (CPrR 5:4n). ${ }^{12}$ While consciousness of the moral law is an underivable "fact of reason" (Factum der Vernunft), admitting of no further proof, Kant argues that we can appeal to this fact to justify our belief in freedom (CPrR 5:31). ${ }^{13}$

In light of such remarks, it is perhaps not surprising that many commentators have come to assume that Fichte rejects the disclosure thesis outright. After all, from what we have discussed so far, Fichte seems committed to the project of deriving consciousness of the moral law, in the manner of a strict deduction, and so he seems committed to going beyond Kant, who was content (rightly or wrongly) to regard such consciousness as the ultimate bedrock of his moral philosophy. Yet, in hindsight, this makes Fichte's reference to Kant at GA I/5:65 all the more enigmatic, since there he invokes the disclosure thesis with approval. Nor has this enigma escaped the attention of Fichte's critics: the passage at GA I/5:65 led one nineteenth-century reader-Christfried Albert Thilo-to argue that Fichte's invocation of Kant is out of tune with the entire aim and organization of his deduction. ${ }^{14}$ As Thilo sees things, instead of exposing the defect of presenting the moral law as a "fact of pure reason," we find Fichte stopping at a Kantian position and asserting "against his will, as it were [gleichsame wider seinen Willen]" that "one has the moral law first and then freedom." Thilo goes even further and argues that Fichte's appeal to Kant undermines the cogency of his argument. For the apparent 
aim of Part I is to deduce the moral law from the absolute freedom of the I; so, by now deriving this freedom from the moral law, Thilo alleges, "his deduction obviously turns in a circle and thus becomes superfluous [so dreht sich seine Deduction offenbar im Kreise und macht sich damit überflüssig]." 15

By way of reply, I want to suggest that Fichte's invocation of Kant is much less mysterious when we place it in the larger context of the book. To start with, we may recall that the task Fichte issued in $\$ 2$, and then reissued in $\$ 3$, was to show how we can become conscious of our tendency to self-activity (GA I/5:53). The reason why our analysis in $\$ 2$ reached a limit was that it only gave us insight into our capacity for free action, and a capacity remains problematic without any "datum" pointing to its actuality. By shifting attention to the I as a subject-object unity in $\$ 3$, Fichte was able to articulate this datum in terms of giving ourselves a fixed law, an insight which, he argued, we attain when we frame our capacity for free action under the aspect of objectivity. What this shows, in my view, is that behind Fichte's claim that the unity of the I is unthinkable, he remains committed to the epistemic primacy of the moral law for specifying the essence of self-sufficiency. ${ }^{16}$ For like Kant, he thinks that the sole datum of the actuality of freedom comes from our awareness of a law to legislate ourselves. In this way Fichte combines-consistently, I would add - both the idea that freedom and morality are mutually interrelated aspects of the same thing (the identity thesis) and the idea that the moral law is the sole medium through which our consciousness of freedom becomes determinate (the disclosure thesis).

This is not to say that commentators have been entirely wrong to detect differences between Fichte's strategy of moral justification and Kant's, but I fear that they have not correctly identified the root of those differences. While Fichte accepts some version of the disclosure thesis, I read him as tacitly rejecting Kant's view that freedom and morality stand in a relation of mutual conceptual entailment, for this assumes that freedom and morality are distinct thoughts sharing content and extension-the two criteria for analytic reciprocity. ${ }^{17}$ While Fichte is willing to follow Kant in identifying the moral law as the epistemic ground of freedom, he is not willing to accept what some scholars call Kant's reciprocity thesis, ${ }^{18}$ because on his account we are not even dealing with an entailment relation here. On Fichte's account, freedom (in the sense of sheer spontaneity) and morality (in the sense of legislation according to the concept of self-sufficiency) form a real synthetic whole, whose separation into subjective and objective parts is merely a product of abstract thinking. The method Fichte employs draws upon a law of reciprocal interaction in order to approach the unthinkable unity of the I. It is for this reason that Fichte offers a multilateral deduction in Part I of the System of Ethics, whose 
final result is that freedom and morality are reciprocal aspects of a single thought.

But what are we to make Thilo's allegation that Fichte's deduction moves in a vicious circle? No one will deny that it is problematic to treat the moral law first as something to be argued for, and then use it as a basis to be argued from-since the first strategy regards the moral law as a conclusion, whereas the second strategy regards it as a presupposition. However, I do not think Fichte is guilty of committing this fallacy, and it is instructive to see why. Part I has both a moral starting point and moral terminus, but what many commentators overlook is that the two are distinct from each other. The starting point is our everyday moral phenomenology, or what Fichte calls:

Moral Compulsion: The feeling of having to perform some actions, simply for the sake of performing them, and the feeling of having to avoid other actions, simply for the sake of avoiding them.

By the end of Part I we are supposed to have acquired genetic cognition of this phenomenon, whereby we see it as the manifestation of a necessary mode of thinking our freedom under law - the ground of which we only apprehend, Fichte argues, from a philosophical point of view. The principle underlying the feeling of moral compulsion is what Fichte formulates as the moral law (das Sittengesetz):

Moral Law: The law the intellect gives to itself - namely, to determine its freedom in accordance with the concept of self-sufficiency without exception.

This shows us that both the "fact" at the starting point of the deduction, and the "ground" of this fact at the terminus, are different ways of approaching moral normativity as such. ${ }^{19}$ The difference is therefore explanatory: the starting point considers moral normativity from the viewpoint of ordinary consciousness, whereas the terminus considers it from the viewpoint of transcendental reflection. In this regard Fichte's deduction aspires to be internally self-grounding, since it does not seek to justify our experience of moral compulsion on the basis of morally-neutral or theoretical premises. Indeed, Fichte even warns the reader against "being misled — as has so often been the case-into wanting to provide a further explanation of our consciousness of having duties (for this is what the thought to be described will prove to be) and wanting to derive it from grounds outside of itself, which is impossible and which would violate the dignity and absoluteness of the law" (GA I/5:60). 
When Fichte then says in agreement with Kant that conviction in our freedom comes from consciousness of the moral law, he is not guilty of arguing in a vicious circle. If we pause to reread the stretch of text I quoted above, it is clear that he is drawing upon the moral law (the terminus), and not the feeling of moral compulsion (the starting point), in an effort to justify our belief in absolute self-activity. Nor is there any inconsistency in this claim, since Fichte has already shown that morality and freedom are but two aspects of one and the same thought, viewed either objectively as a fixed law or subjectively as sheer spontaneity. ${ }^{20}$ The moral law demands that we legislate ourselves according to the concept of self-sufficiency without exception. And this is just the objective manner of thinking our own freedom, which otherwise appears to us as a fact of consciousness. When the question then becomes, "On what basis should we should assent to this appearance?" it makes sense for Fichte to invoke the moral law, since this law is the datum for the positive determination of our freedom. That is why, if "one does not go beyond the moral law, then one also does not go beyond the appearance of freedom, which thereby becomes for us the truth" (GA I/5:65). The moral law in this way supports a fundamental decision for Fichte—one which his "entire philosophy is built upon" (GA I/5:43) - the decision to say, "I am free," and not merely, "I appear to myself to be free" (GA I/5:65).

\section{Conclusion: The Science of Ethics}

Whenever interpreting a philosophical argument, it is important to ask what it ultimately aims to accomplish. On the reading I have defended in this chapter, Fichte's deduction of the moral law seeks to trace our feeling of moral compulsion (as a "fact of consciousness") to its highest ground, and the argument culminates in his thesis that morality and freedom are but two aspects of the I as such, considered either objectively or subjectively. For all its complexity, then, the goal of Fichte's deduction is simply to vindicate our common consciousness of moral normativity by revealing its rational source. It aims at nothing more than knowledge of our ethical nature, ${ }^{21}$ and Fichte is clear that knowledge is not power $($ Kraft $)$ :

In this way, while we gain insight into the grounds [of this compulsion] by means of a deduction, we do not gain any power to change this compulsion, because it is our knowledge, not our power, that reaches this far, and because the whole relation is necessary-it is our own unchangeable nature itself. The 
deduction therefore produces nothing more than theoretical cognition, and one must not expect anything more from it. (GA I/5:33)

At the same time, theoretical cognition of our ethical nature is not a small or insignificant achievement. For it is precisely this cognition that links the doctrine of ethics (Sittenlehre) to the doctrine of science (Wissenschaftslehre) and thereby brings a science of morality into being - "and science, wherever it is possible, is an end in itself" (GA I/5:33). ${ }^{22}$

\section{Notes}

1. For clear statements to this effect, see Yukio Irie, "Der transzendentale Beweis der Sittlichkeit bei Fichte," Philosophia OSAKA 1 (2006): 13; Jacinto Rivera de Rosales, "The Transcendental Deduction of the Categorial Imperative in Fichte's System of Ethics," Philosophy Today 52 (2008): 237; Reinhard Brandt, "Die Freiheit der Reflexion und die Furie des Deduzierens," in Symposion: Johann Gottlieb Fichte: Herkunft und Ausstrahlung seines Denkens, ed. Werner Beierwaltes and Erich Fuchs (Munich: Bayerische Akademie der Wissenschaften, 2009), 13; Walter Jaeschke and Andreas Arndt, Die Klassische Deutsche Philosophie nach Kant: Systeme der reinen Vernunft und ibre Kritik 1785-1845 (Munich: C.H. Beck, 2012), 121-22; and Paul Guyer, "Fichte's Transcendental Ethics," in The Transcendental Turn, ed. Sebastian Gardner and Matthew Grist (Oxford: Oxford University Press, 2015), 146-47. For an important exception to this trend, to which I am indebted, see Allen W. Wood, Fichte's Ethical Thought (Oxford: Oxford University Press, 2016).

2. See Christfried Albert Thilo, "Die Grundirrthümer des Idealismus in ihrer Entwickelung von Kant bis Hegel," Zeitschrift für exacte Philosophie im Sinne des neuern philosophischen Realismus 1 (1861): 345. As we shall see, Thilo believed that Fichte held an inconsistent position, first seeking to derive the moral law from the absolute freedom of the I, and then reverting to a Kantian position and deriving freedom from consciousness of the moral law.

3. This helps to explain Fichte's otherwise confusing remark that a "doctrine of ethics" (Sittenlehre) is "a theory of consciousness of our moral nature in general and of our specific duties in particular" (GA I/5:35).

4. This distinction between a "unilinear" and "multilateral" style of deduction comes from an excellent essay by Daniel Breazeale, "Circles and Grounds," in Thinking Through the Wissenschaftslehre: Themes from Fichte's Early Philosophy (Oxford: Oxford University Press, 2013), 272-300, which traces a methodological shift between the early and late versions of Fichte's Jena system (294). Without going into this larger topic, I wish to apply Breazeale's distinction to 
the specific context of Fichte's deduction of the moral law in the System of Ethics.

5. To be clear, the derivation proper concerns the feeling of compulsion. This is what requires a genetic proof. As we shall see, Fichte will also derive (in a thinner sense of the word) a formula of the moral law in terms of acting "according to the concept of self-sufficiency, absolutely and without exception" (GA $\mathrm{I} / 5: 69)$. This is not a genetic derivation, however, since the moral law turns out to be merely an objective manner of thinking our own freedom.

6. In lecture transcripts titled The Doctrine of Science, New Method (Wissenshaftslehre nova methodo) dating from 1796 to 1799, we find Fichte distinguishing three kinds of synthetic method: (1) "in which one proceeds from a contradiction and seeks to resolve it'; (2) "another method is: to begin by posing for oneself a principal task, and then seek to accomplish this task by introducing intermediate principles'; (3) "A third synthetic method is: to clarify gradually what remained previously obscure and indeterminate" (GA IV/2:107-108). Although the first procedure is the official methodology of Part I of the System of Ethics, Fichte will invoke the second at a critical juncture in $\$ 3$, as we shall see below. For a helpful account of Fichte’s methodology beyond the System of Ethics, see G. Anthony Bruno, "Genealogy and Jurisprudence in Fichte's Genetic Deduction of the Categories," History of Philosophy Quarterly 35 (2018): 77-96.

7. Fichte argues that what makes an intellect free to determine itself is that it has no pre-fixed or pre-given nature. It exists, as he puts it, "prior to its nature" (GA I/5:51; emphasis added).

8. Fichte explicitly denies that it can manifest as a feeling (Gefühl). For further discussion, see Andreas Schmidt, "Die Deduktion des Prinzips der Sittlichkeit (\$\$1-3)," in Fichtes System der Sittenlehre: Ein kooperativer Kommentar, ed. Jean-Christophe Merle and Andreas Schmidt (Frankfurt: Klostermann, 2015), 49.

9. As Fichte explains, while we can never think of what is subjective and objective in the I together, we can think of the two "next to each other [nebeneinander] and after each other [Nacheinander]; and through this thinking one after each other [Nacheinanderdenken]," he adds, "we make each of them reciprocally dependent [wechselseitig... abhängig] on the other" (GA I/5:56).

10. Although Fichte does not speak of an "antinomy" between a thesis and an antithesis, Wood has made a very compelling case for reading GA I/5:58 along these lines. See Wood, Fichte's Ethical Thought, 119.

11. My inspiration for this diagram comes from Kuno Fischer, although Fischer's original version is somewhat flawed, since below the first objective aspect of the I he subsumes "stuff" instead of "will." See Fischer, Fichte und Seine Vorgänger, 2nd ed. (Munich: Bassermann, 1874), 571.

12. This is Mary Gregor's translation in Practical Philosophy, ed. Allen W. Wood (Cambridge: Cambridge University Press, 1996). 
13. As Kant puts it later on: "The moral law, which itself has no need of justifying grounds, proves not only the possibility but also the reality [of freedom] in beings who cognize this law as binding upon them" (CPrR 5:47). I discuss Kant's project of moral justification at greater length elsewhere. See Owen Ware, "Rethinking Kant's Fact of Reason," Philosophers' Imprint 14 (2014): 1-21; and Owen Ware, "Kant's Deductions of Morality and Freedom," Canadian Journal of Philosophy 47 (2017): 116-47.

14. Thilo, "Die Grundirrthümer des Idealismus," 345. With the exception of Wood (Fichte's Ethical Thought), Fichte's reference to the Factum of reason at GA I/5:65 is largely ignored by scholars. It goes unmentioned, for example, in Schmidt's otherwise thorough commentary on Part I ("Die Deduktion des Prinzips der Sittlichkeit"). Binkelmann cites it, but only briefly: Christoph Binkelmann, Theorie der praktischen Freiheit: Fichte-Hegel (Berlin: de Gruyter, 2007), 79-80. Although this topic goes beyond the scope of the present chapter, it is important to note in passing that the word Factum carries two distinct but related senses: (a) "something done" and (b) "something immediately present to consciousness." Kant's Factum der Vernunft arguably combines the two. For further discussion, see Ware, "Rethinking Kant's Fact of Reason," 2-9.

15. Thilo, "Die Grundirrthümer des Idealismus," 345.

16. In the "Second Introduction" to the Attempt at a New Presentation of the Wissenschaftslehre (1797), Fichte also insists that there is only one way to warrant faith (Glaube) in the reality of freedom, namely, "through the presentation of the moral law within us [durch Aufweisung des SittenGestzes in uns]" (GA I/4:219). "Intuition of self-activity and freedom are grounded in consciousness of this law, which is without doubt not derived from anything else, but is an immediate consciousness" (GA I/4:466). Therefore, it is "only through this medium of the moral law that I catch a glimpse of myself, and when I see myself in this way, I necessarily see myself as self-active" (GA I/4:219). Just how early this particular commitment goes back in Fichte's intellectual development remains a topic of scholarly dispute. For a clear overview, see Frederick C. Beiser, German Idealism: The Struggle against Subjectivism, 1781-1801 (Cambridge: Harvard University Press, 2002), Part II.

17. I agree with Wood that if we interpret Kant's Factum as a deed of reason, whose normative authority we are immediately conscious of, "then Kant and Fichte are not far apart" (Fichte's Ethical Thought, 123). (See the footnote at GA I/2:396 for evidence that this is how Fichte read Kant's Factum too.) However, Wood goes on to explain Fichte's rejection of Kant's reciprocity thesis by focusing on the formula of autonomy.

Kant thinks freedom and the law are distinct (but co-implying) thoughts because he is referring to a specific law.... The formula of autonomy co- 
implies freedom, at least freedom in the positive sense of the term (G $4: 446-7, \mathrm{KpV} 5: 28-31$ ), but it is not the same thought as freedom. Fichte's principle of morality, however, has no specific content. It really is the same as Kant's "fact [or deed] of reason." The moral principle says only that wherever moral authority applies to an act, that act must be done. (Fichte's Ethical Thought, 123)

While it is true that Fichte has yet to spell out the applicability or application of the moral law (two tasks he postpones for later in the book), he nevertheless derives a formula for the moral law in Part I, which he summarizes in a subsection titled "Description of the principle of morality according to this deduction" (GA I/5:59). In my view, Fichte denies the real conceptual separateness of freedom and morality on the grounds of his commitment to an absolutely unified first principle, which he thinks Kant lacks.

18. This label comes from Henry E. Allison, "Morality and Freedom: Kant's Reciprocity Thesis," Philosophical Review 95 (1986): 393-425.

19. Fichte devotes the final paragraph of Part I (GA I/5:70-71) to preventing certain "misunderstandings and objections" that may linger in the mind of the reader, and here he argues explicitly that the moral law (in its abstract formulation as a principle of self-sufficiency) is not a fact (Thatsache) of common consciousness (GA I/5:71). What is a Thatsache, he claims, is a feeling that certain actions are either obligatory or forbidden, without those actions bearing any connection to our self-interest (GA I/5:71). A surprising number of Fichte scholars conflate "compulsion" (or "conscience") and the "moral law" in their treatments of Part I.

20. Nor does this conflict with Fichte's earlier point about having factual cognition of our ethical nature, for there he is referring to the feeling of compulsion. At the level of common consciousness, attaching unconditional faith (unbedingten Glauben) to this feeling - and regarding it as an expression of our highest vocation (böchste Bestimmung) — is sufficient for having a dutiful disposition (pflichtmässigen Gesinnung) (GA I/5:14).

21. This feature of Fichte's deduction is explored in further detail by Benjamin Crowe: "The Character of Fichte's Metaethics," in Fichte's System of Ethics: A Critical Guide, ed. Stefano Bacin and Owen Ware (Cambridge: Cambridge University Press, forthcoming).

22. For feedback on earlier versions, I would like to thank Gabriele Gava, Steven Hoeltzel, and participants in my 2018 Fichte seminar at the University of Toronto. I owe a special debt of gratitude to Anthony Bruno and Kienhow Goh, whose astute critical observations were decisive in helping me refine the views I propose in this chapter. 